\title{
Pectin and Pectinases: Production, Characterization and Industrial Application of Microbial Pectinolytic Enzymes
}

\author{
Danielle Biscaro Pedrolli ${ }^{1}$, Alexandre Costa Monteiro $^{2}$, Eleni Gomes ${ }^{2}$ and Eleonora Cano Carmona ${ }^{1, *}$ \\ ${ }^{I}$ Departamento de Bioquímica e Microbiologia, Instituto de Biociências, Universidade Estadual Paulista - UNESP, \\ 13506-900, Rio Claro, SP, Brazil and ${ }^{2}$ Departamento de Biologia, Instituto de Biociências, Letras e Ciências Exatas, \\ Universidade Estadual Paulista - UNESP, 15054-000, São José do Rio Preto, SP, Brazil
}

\begin{abstract}
Pectinases are a big group of enzymes that break down pectic polysaccharides of plant tissues into simpler molecules like galacturonic acids. It has long been used to increase yields and clarity of fruit juices. Since pectic substances are a very complex macromolecule group, various pectinolytic enzymes are required to degrade it completely. These enzymes present differences in their cleavage mode and specificity being basically classified into two main groups that act on pectin "smooth" regions or on pectin "hairy" regions. Pectinases are one of the most widely distributed enzymes in bacteria, fungi and plants. This review describes the pectinolytic enzymes and their substrates, the microbial pectinase production and characterization, and the industrial application of these enzymes.
\end{abstract}

Key Words: Pectinase, pectinolytic, pectin.

\section{INTRODUCTION}

The increasing energy demands have focused worldwide attention on the utilization of renewable resources, particularly agricultural and forest residues, the major components of which are cellulose, starch, lignin, xylan and pectin. These materials have attracted considerable attention as an alternative feedstock and energy source, since they are abundantly available. Several microbes are capable of using these substances as carbon and energy sources by producing a vast array of enzymes in different environmental niches [1,2].

Pectinase production occupies about $10 \%$ of the overall manufacturing of enzyme preparations. Pectinolytic enzymes are widely used in the food industry for juice and wine production [3].

This review describes the pectinolytic enzymes and their substrates, the microbial pectinase production and characterization, and the industrial application of these enzymes.

\section{PECTIC SUBSTRATES}

Pectic substances are complex high molecular mass glycosidic macromolecules found in higher plants. They are present in the primary cell wall and are the major components of the middle lamellae, a thin extracellular adhesive layer formed between the walls of adjacent young cells. In short, they are largely responsible for the structural integrity and cohesion of plant tissues [4, 5].

Three major pectic polyssacharides groups are recognized, all containing D-galacturonic acid to a greater or a lesser extent.

*Address correspondence to this author at the Departamento de Bioquímica e Microbiologia, Instituto de Biociências, Universidade Estadual Paulista, UNESP, Avenida 24A, 1515, CEP 13506-900 Rio Claro, SP, Brazil; Tel: 55 (19) 35264175; Fax: 55 (19) 35264176; E-mail: ecarmona@rc.unesp.br

\subsection{Homogalacturonan (HG)}

HG is a linear polymer formed by D-galacturonic acid which can be acetylated and/or methyl esterified. It can be called smooth regions of pectin. The molecule is classified according to its esterification level: pectin has at least $75 \%$ of the carboxyl groups methylated; pectinic acid has less than $75 \%$ of the carboxyl groups methylated; pectic acid or polygalacturonic acid has no methyl esterified carboxyl groups. Frequently the word pectin is used as a generic name for pectic substances [6].

\subsection{Rhamnogalacturonan I (RGI)}

RG I is composed of the repeating disaccharide rhamnose-galacturonic acid. The galacturonic residues can be acetylated and both residues can carry side chains of neutral sugars as galactose, arabinose and xylose [7].

\subsection{Rhamnogalacturonan II (RGII)}

Despite its name, RGII is a homogalacturonan chain with complex side chains attached to the galacturonic residues [7]. Vincken and coworkers [8] have proposed a pectin molecule structure model in which HG and RGII are long side chains of RGI backbone (Fig. 1). Both RG chains are also called hairy regions of pectin molecule.

In unripe fruit, pectin is found as a water insoluble pectic substance, the protopectin, bounded to cellulose microfibrils conferring rigidity on cell walls. During ripening the fruit enzymes alter the pectin structure by breaking the pectin backbone or side chains, resulting in a more soluble molecule [9].

Pectic subsances tend to form a gel structure when portions of HG are cross-linked forming a three dimensional crystalline network in which water and solutes are trapped 

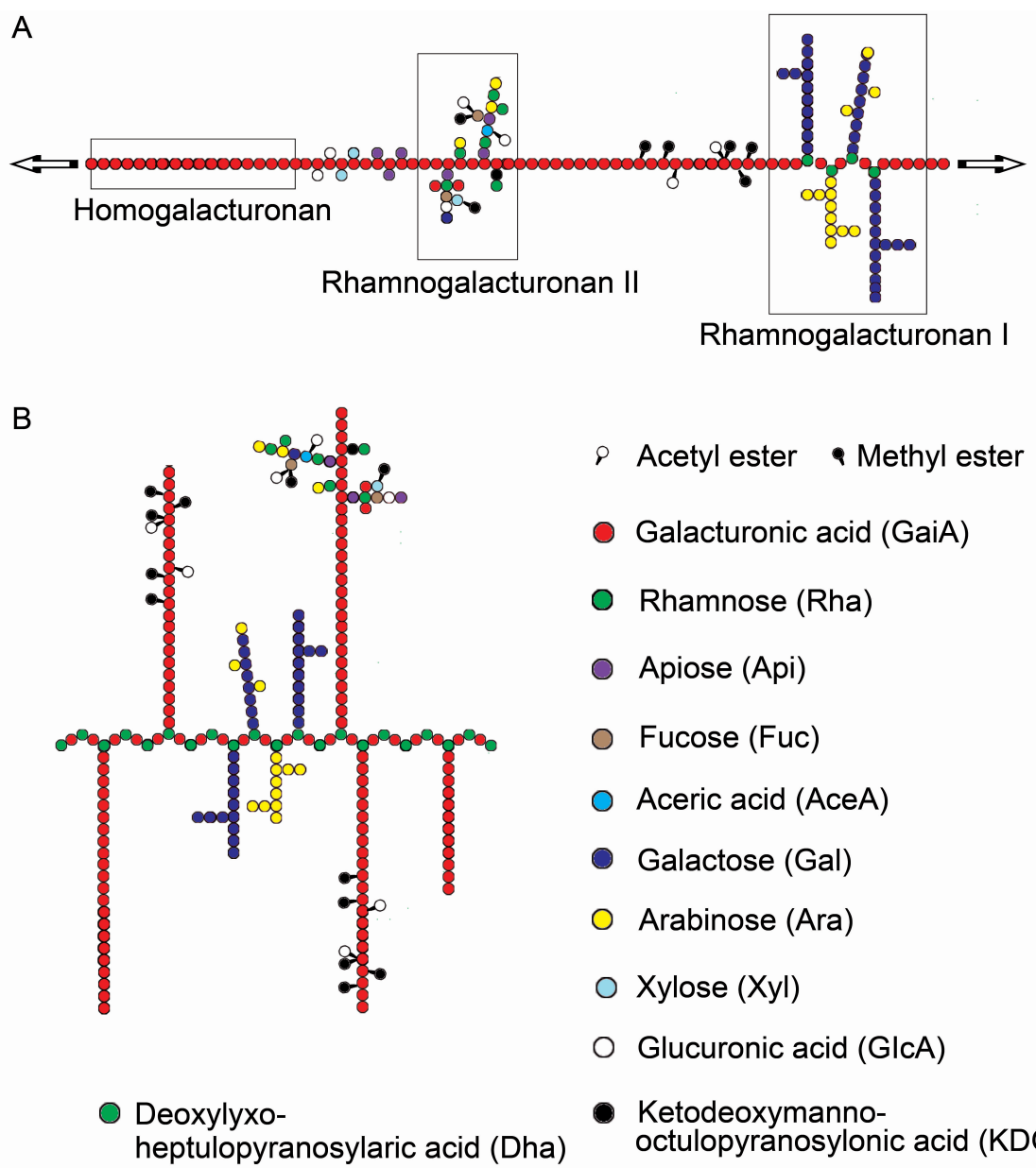

Acetyl ester Methyl ester
Galacturonic acid (GaiA)
Rhamnose (Rha)
Apiose (Api)
Fucose (Fuc)
Aceric acid (AceA)
Arabinose (Ara)
Xylose (Xyl)
Glucuronic acid (GlcA)
Ketodeoxymanno-
octulopyranosylonic acid (KDO)

Fig. (1). The basic structure of pectin. Schematic representations of the conventional (A) and recently proposed alternative (B) structures of pectin. The polymers shown here are intended only to illustrate the some of the major domains found in most pectins rather than definitive structures. [7].

(Fig. 2). Various factors determine gelling properties including temperature, pectin type, esterification degree, acetylation degree, $\mathrm{pH}$, sugar and other solutes, and mainly the interaction between calcium ions and pectin unesterified carboxyl groups. In high-ester pectins, the junction zones are formed by the cross-linking of HG by hydrogen bridges and hydrophobic forces between methoxyl groups, both promoted by high sugar concentration and low $\mathrm{pH}$ [7].

Pectic polysaccharides have been used as bioactive food ingredients and as detoxifying agents. It is an adequade infant food supplement [10].

\section{PECTINOLYTIC ENZYMES}

Pectinases are an enzyme group that catalyzes pectic substance degradation through depolymerization (hydrolases and lyases) and deesterification (esterases) reactions.

The well-known pectinolytic enzymes are homogalacturonan degrading enzymes. Fig. (3) shows the action mode of the most studied pectinases.

\subsection{Protopectinases}

Protopectinases solubilize protopectin forming highly polymerized soluble pectin $[5,9]$. They are classified into two types: one reacts with the polygalacturonic acid region of protopectin, A type; the other with the polysaccharide chains that may connect the polygalacturonic acid chain and cell wall constituents, B type [12].

\subsection{Pectin Methyl Esterases (PME)}

Pectin methyl esterase or pectinesterase (EC 3.1.1.11) catalyzes deesterification of the methoxyl group of pectin forming pectic acid and methanol. The enzyme acts preferentially on a methyl ester group of galacturonate unit next to a non-esterified galacturonate unit. It acts before polygalacturonases and pectate lyases which need non-esterified substrates [9]. It is classified into carbohydrate esterase family 8 [13].

\subsection{Pectin Acetyl Esterases (PAE)}

Pectin acetyl esterase (EC 3.1.1.-) hydrolyses the acetyl ester of pectin forming pectic acid and acetate [14]. It is classified into carbohydrate esterase families 12 and 13 [13].

\subsection{Polymethylgalacturonases (PMG)}

Polymethylgalacturonase catalyzes the hydrolytic cleavage of $\alpha$-1,4-glycosidic bonds in pectin backbone, preferentially highly esterified pectin, forming 6-methyl-D-galacturonate [6]. 


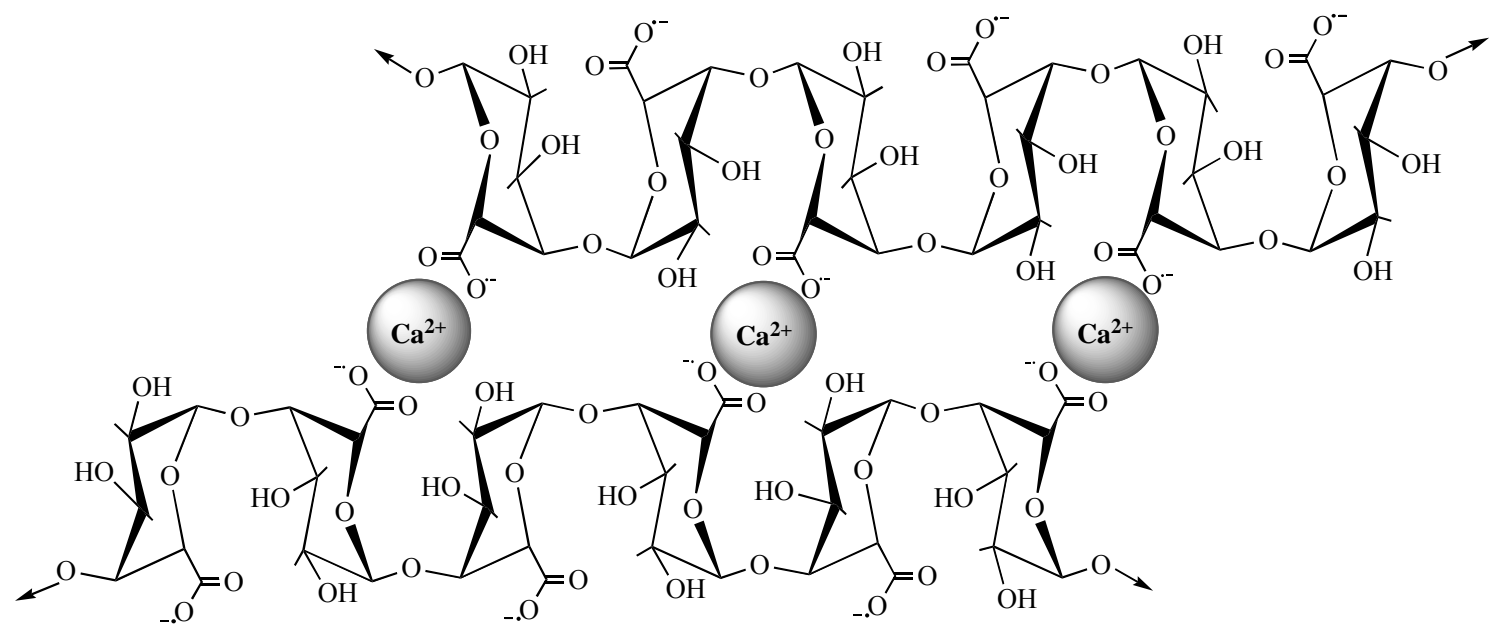

Fig. (2). Interaction through insertion of $\mathrm{Ca}^{2+}$ ions between the unesterified carboxyl groups of the galacturonosyl residues of two $\mathrm{HG}$ chains [8].

(a)

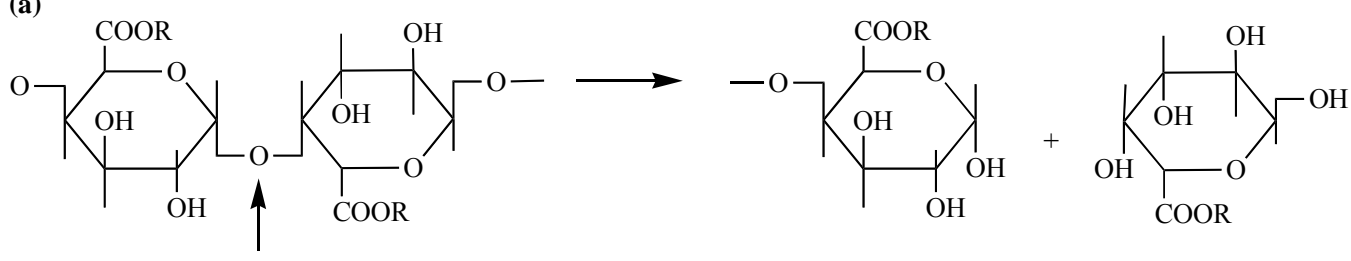
PMG/PG

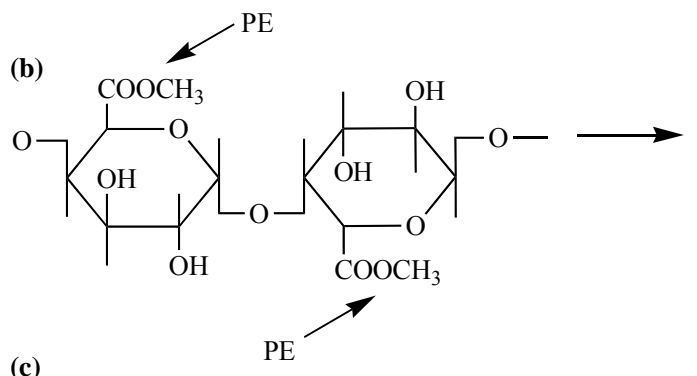

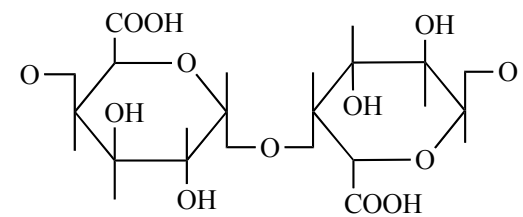

(c)

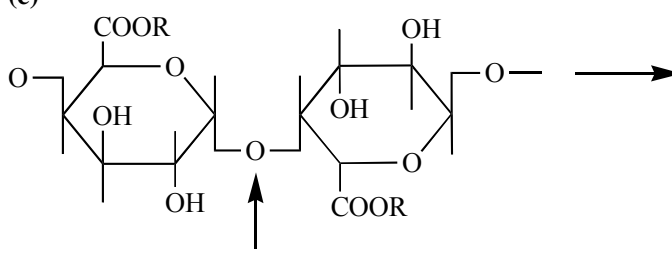<smiles>[R]OC(=O)C1=CC(C)(O)C(C)(O)C(C)(CO)OC1(C)O</smiles>

PL/PGL

Fig. (3). Mode of action of pectinases: (a) $\mathrm{R}=\mathrm{H}$ for $\mathrm{PG}$ and $\mathrm{CH}_{3}$ for $\mathrm{PMG}$; (b) PE; and (c) $\mathrm{R}=\mathrm{H}$ for PGL and $\mathrm{CH}$ for $\mathrm{PL}$. The arrow indicates the place where the pectinase reacts with the pectic substances. PMG, polymethylgalacturonases; PG, polygalacturonases (EC 3.2.1.15); PE, pectinesterase (EC 3.1.1.11); PL, pectin lyase (EC-4.2.2.10) [11].

\subsection{Polygalacturonases (PG)}

Polygalacturonase catalyzes hydrolysis of $\alpha$-1,4-glycosidic linkages in polygalacturonic acid producing D-galacturonate. It is classified into glycosyl-hydrolases family 28 [13].

Both groups of hydrolase enzymes (PMG and $\mathrm{PG}$ ) can act in an endo- or exo- mode. Endo-PG (EC 3.2.1.15) and endo-PMG catalyze random cleavage of substrate, exo-PG (EC 3.2.1.67) and exo-PMG catalyze hydrolytic cleavage at substrate nonreducing end producing monogalacturonate or digalacturonate in some cases [4, 9]. Hydrolases are produced mainly by fungi, being more active on acid or neutral medium at temperatures between $40^{\circ} \mathrm{C}$ and $60^{\circ} \mathrm{C}$, as shown in Table $\mathbf{1}$.

\subsection{Pectate Lyases (PGL)}

Pectate lyase cleaves glycosidic linkages preferentially on polygalacturonic acid forming unsaturated product $(\Delta$ - 
Table 1. Properties of Some Purified Polygalacturonases

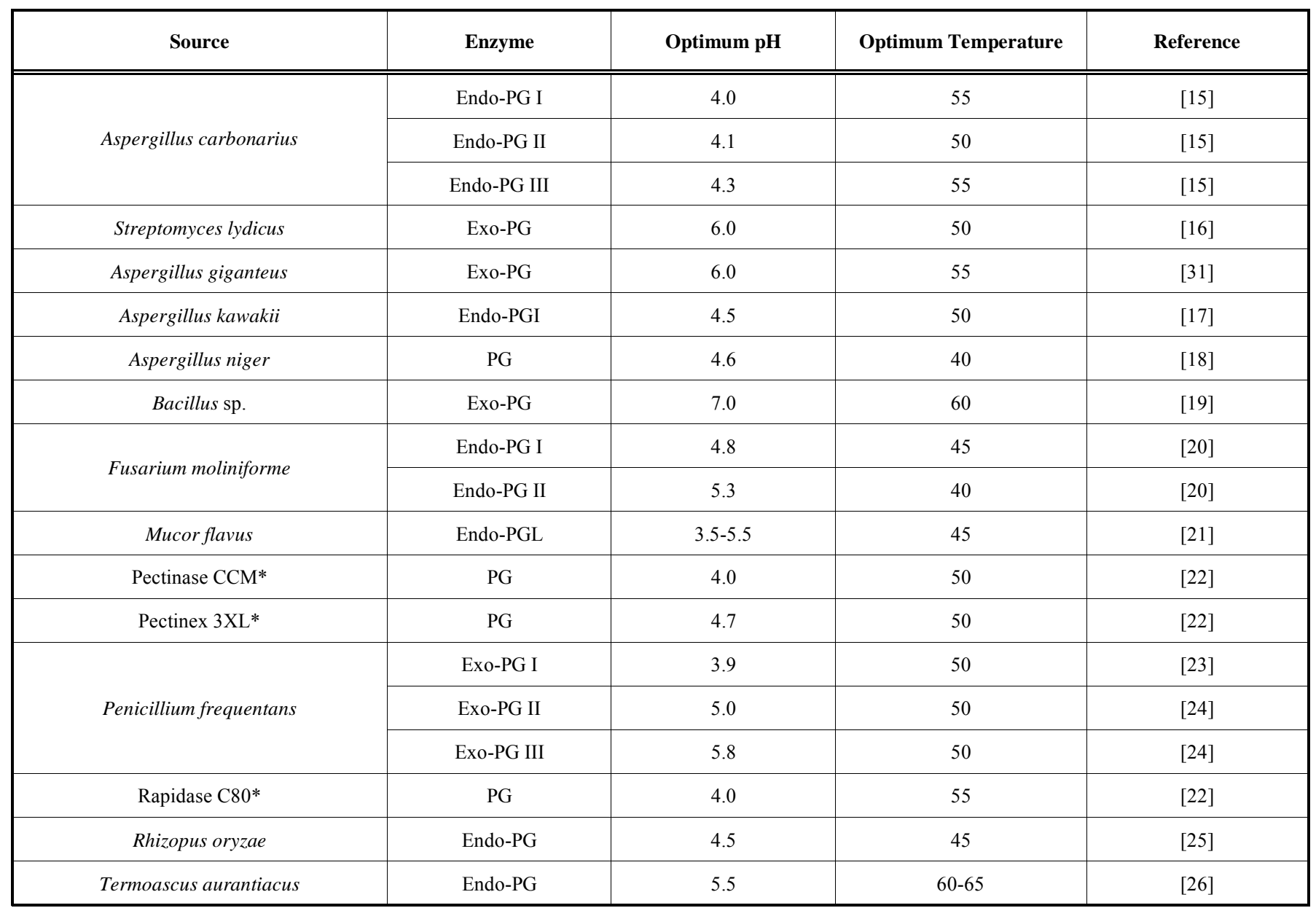

*Commercial names.

4,5-D-galacturonate) through transelimination reaction. PGL has an absolute requirement of $\mathrm{Ca}^{2+}$ ions. Hence it is strongly inhibited by chelating agents as EDTA [6]. Pectate lyases are classified as endo-PGL (EC 4.2.2.2) that acts towards substrate in a random way, and exo-PGL (EC 4.2.2.9) that catalyze the substrate cleavage from nonreducing end [4, 27].

\subsection{Pectin Lyases (PL)}

Pectin lyase catalyzes the random cleavage of pectin, preferentially high esterified pectin, producing unsaturated methyloligogalacturonates through transelimination of glycosidic linkages. PLs do not have an absolute requirement of $\mathrm{Ca}^{2+}$ but they are stimulated by this and other cations [6]. Up until now, all described pectin lyases are endo-PLs (EC 4.2.2.10) [28]. Van Alebeek and coworkers [29] conducted a detailed study of the action mode of pectin lyase A from Aspergillus niger which produces mono-, di-, tri- and tetragalacturonates, besides unsaturated di-, tri- and tetragalacturonates from methyloligogalacturonates. Unsaturated monogalacturonates were not identified in the reaction products in any assay.

Both lyase groups are classified into polysaccharideslyase family 1 . As shown in Table 2 , lyases from fungi present optimum activity in acid and neutral medium, while those from bacteria are more active in alkaline medium.
Complete degradation of pectin substrate still requires enzymes that cleave the rhamnogalacturonan chain.

\subsection{Rhamnogalacturonan Rhamnohydrolases}

RG rhamnohydrolase, rhamnogalacturonan $\alpha$-Lrhamnopyranohydrolase or $\alpha$-L-rhamnosidase (EC 3.2.1.40) catalyzes hydrolytic cleavage of the rhamnogalacturonan chain at nonreducing end producing rhamnose [40]. These enzymes are classified into glycosyl-hydrolase families 28 , 78 and 106 [13].

\subsection{Rhamnogalcturonan Galacturonohydrolases}

RG galacturonohydrolase (EC 3.2.1.-) catalyzes hydrolytic cleavage of the rhamnogalacturonan chain at nonreducing end producing monogalacturonate [41]. It is classified into glycosyl-hydrolase family 28 [13].

\subsection{Rhamnogalacturonan Hydrolases}

RG hydrolase randomly hydrolyses the rhamnogalacturonan chain producing oligogalacturonates [41].

\subsection{Rhamnogalacturonan Lyases}

RG lyase (EC 4.2.2.-) catalyzes the random transelimination of the rhamnose-galcturonate linkage from rhamnoga- 
Table 2. Properties of Some Purified Lyases

\begin{tabular}{|c|c|c|c|c|}
\hline Source & Enzyme & Optimum pH & Optimum Temperature $\left({ }^{\circ} \mathbf{C}\right)$ & Reference \\
\hline Aspergillus japonicus & PL & $4.5-5.5$ & - & {$[30]$} \\
\hline \multirow[b]{2}{*}{ Aspergillus niger } & PGL (PeL I) & 6.0 & 50 & {$[18]$} \\
\hline & PGL (PeL II) & 4.6 & 50 & {$[18]$} \\
\hline Bacillus macerans & PGL & $8.0-8.5$ & $63-67$ & {$[32]$} \\
\hline Bacillus pumilus & PGL & 8.5 & 70 & {$[33]$} \\
\hline Bacillus sp. DT7 & PL & 8.0 & 60 & {$[34]$} \\
\hline Debaryomyces nepalensis & PGL & 7.5 & 32 & [37] \\
\hline Grindamyl 3PA* & PL & 6.0 & 40 & {$[38]$} \\
\hline Paenibacillus barcinonensis & PGL (Pel A) & 10.0 & 55 & [36] \\
\hline Pectinase $\mathrm{CCM}^{*}$ & PL & 6.0 & 40 & {$[38]$} \\
\hline Pectinex $3 \mathrm{XL}^{*}$ & PL & $5.0-6.5$ & 35 & {$[38]$} \\
\hline Penicillium canescens & PL A & $5.0-5.5$ & 60 & {$[28]$} \\
\hline Penicillium italicum & PL (PNL) & $6.0-7.0$ & 50 & [39] \\
\hline
\end{tabular}

* Commercial names.

lacturonan chain, producing an unsaturated galacturonate at nonreducing end of one oligomer and a second oligomer containing a rhamnose as a reducing end residue [42]. These enzymes are classified into polysaccharides-lyase families 4 and $11[13]$.

\subsection{Rhamnogalacturonan Acetylesterases}

RG acetylesterase (EC 3.1.1.-) catalyzes hydrolytic cleavage of acetyl groups from rhamnogalacturonan chain [43]. It is classified into carbohydrate esterase family 12 [13].

\subsection{Xylogalacturonan Hydrolase}

Xylogalacturonase (EC 3.2.1.-) catalyzes hydrolytic cleavage of glycosidic linkages between two galacturonate residues in xylose-substituted rhamnogalacturonan chain, producing xylose-galacturonate dimers [44]. These enzymes are classified into glycosyl-hydrolase family 28 [13].

\section{MICROBIAL PECTINASES}

Pectinolytic enzymes are naturally produced by many organisms like bacteria, fungi, yeasts, insects, nematodes, protozoan and plants. Microbial pectinases are important in the phytopathologic process, in plant-microbe symbiosis and in the decomposition of dead plant material, contributing to the natural carbon cycle. Pectinases are abundantly produced by saprophytic fungi, and decaying plant tissue represents the most common substrate for pectinase-producing microorganisms [10]. Plant attack by pathogenic microorganisms usually starts by pectinolytic enzymes attack since pectic substances are more accessible than other fibers in plant tissue $[4,45]$.

Several studies on microbial enzymes have shown the production of multiple pectinase forms which differ on molecular mass and kinetic properties [15, 46, 47]. The production of multiple forms of enzymes improves the microorganism ability to adapt to environmental modifications [48]. The cell wall is the first defense line of plants, having a crucial role in preventing infections. It consists mainly of the large biopolymers cellulose, hemicellulose, lignin and pectin; however, the composition can change according to the age and physiological conditions of the plant. In such case, the pathogenic microorganism needs to produce a pool of enzymes to successfully infect the plant tissue $[49,50]$.

Most of the pathogenic microorganisms produce a large variety of plant cell wall enzymes and some studies have shown that, in this regard, polygalacturonases play an important role in virulence of some fungi and bacteria. Kars and coworkers [50] reported a reduction in Botrytis cinerea virulence after deletion of Bcpg2 gene which codifies a polyga- 
lacturonase. PGs are also important in some other fungi and bacteria virulence like Aspergillus flavus, Alternaria citri, Claviceps purpurea, Agrobacterium tumefaciens and Ralstonia solanacearum [51-53].

Pectic substances are rich in negatively charged or methyl-esterified galacturonic acid. The esterification level and the distribution of esterified residues along the pectin molecule change according to the plant life cycle and between different species. Thus, the ability of some phytopathogenic microorganisms to poduce a variety of pectinolytic enzymes that differ in their characteristics, mainly in their substrate specifity, can provide them with more efficacy in cell wall pectin degradation and consequently more success in the plant infection [54].

Several polygalacturonases can be expressed from only one gene or from some different genes. Caprari and coworkers [55] reported the production of four endo-polygalacturonases by the pathogenic fungus Fusarium moniliforme that differ in the extent of glycosylation of the same polypeptide arisen one gene. On the other hand, the polygalacturonases of Aspergillus niger are encoded by a family of diverged genes. The PG isozymes present significant differences in substrate specificity, kinetic parameters and optimum $\mathrm{pH}[56,57]$. The polygalacturonases isozymes produced by the phytopathogenic fungus Botrytis cinerea have been isolated by using different fermentation conditions [5864].

Most of the plant cell wall degrading enzymes are encoded by a large multigenic family showing diverged expression pathways suggesting functional specialization [65]. These genic families result from gene duplication and are linked in tandem [66].

Since pectin can not enter the cell, it has been suggested that compounds structurally related to this substrate might induce pectic enzyme productions by microorganisms. Low levels of constitutive activities may attack the polymeric substrate and release low molecular products which act as inducers $[67,68]$.

De Vries and coworkers [69] had studied the expression of 26 pectinolytic genes from Aspergillus niger under 16 different growth conditions to obtain an expression profile for each gene. Their results provide strong indication for a general activating system for pectinolytic gene expression in A. niger responding to the presence of D-galacturonic acid or a metabolite derived from it. This system regulates both genes encoding enzymes acting on the main chain of pectin as well as genes encoding accessory enzymes. Regulation of the pectinolytic genes appears to be complex, individual genes are expressed at different times and in response to different D-galacturonic acid containing carbon sources.

Submerged fermentation $(\mathrm{SmF})$ and solid state fermentation (SSF) have been successfully used in pectinase production by fungi $[18,70-72]$ and by bacteria $[16,33,34,36,73]$.

Submerged fermentation is a well developed system used in industrial scale to produce a large variety of microbial metabolites. SmF is technically easier than SSF and has been strongly developed from the 1940s onwards because of the necessity to produce antibiotics in large scale [74].
On the other hand, solid state fermentation provides higher productivity due to larger enzyme yields [75]. SSF processes simulate the living conditions of many higher filamentous fungi. Ascomycetes, basidiomycetes and deuteromycetes developed in terrestrial habitats on wet substrates. Higher fungi and their enzymes, as well as spores or metabolites, are well adjusted to growth on solid wet substrates. For instance, fungal spores produced by SSF show higher stability, are more resistant to drying and exhibit higher germination rates for extended periods of time after freeze-drying than do spores produced by SmF. Solid state fermentation has only found restricted applications in processes using unicellular organisms. Despite the advantages, the industrial application of SSF is, at least at present, hard to envisage. The main obstacles are the low amenability of the process to regulation, the strongly heterogeneous fermentation conditions and the ensuing frequently unsatisfactory reproducibility of the results, difficult scale-up, the often unfeasible biomass determination and complicated product purification by downstream processes resulting from the use of heterogeneous organic growth substrates [74].

\section{PURIFICATION OF PECTINOLYTIC ENZYMES}

The analysis of enzyme activity in the crude extract does not indicate either an isolated action or the presence of a multienzymic system working in synergy on the substrate degradation. The characterization of purified enzymes is an important research line since it provides discrimination between the enzymic complex components about substrate degradation mechanism, optimum activity conditions and enzyme synthesis regulation.

Contreas-Esquivel and Voget [17] purified 470 fold the PGI from a culture extract of Aspergillus kawakii with a recovery of $8.6 \%$ of the initial activity in three steps: acetone precipitation, Sepharose Q and Sephacryl S-100 column chromatographies. The PG from Thermoascus aurantiacus was isolated with 21 fold increase in specific activity with a recovery of $24.6 \%$ by Sephadex G-75 gel filtration followed by SP-Sepharose ion exchange chromatography [26]. Celestino and coworkes [76] purified 9.37 fold one pectinase produced by Acrophialophora nainiana which has exopolygalacturonase and pectin lyase activity, $60.6 \%$ of the enzyme was recovered after three steps: Sephacryl S-100 gel filtration, DEAE-Sepharose ion exchange and another gel filtration on Sephadex G-50. Kashyap and coworkers [34] developed a purification strategy for the isolation of the pectin lyase from Bacillus sp. DT7. The enzyme was precipitated with ammonium sulphate followed by DEAE-Sephacel and Sephadex G-150 column chromatographies. The pectin lyase produced by Aspergillus flavus was purified 58 fold with a recovery of $10.3 \%$ of the initial activity in three steps: ammonium sulphate fraction, DEAE-Cellulose ion exchange and Sephadex G-100 gel filtration [77]. Semenova and coworkers [30] isolated five pectinases produced by Aspergillus japonicus, PGI, PGII, PEI, PEII and PL, by hydrophobic and ion exchange column chromatographies. The polygalacturonase from Streptomyces lydicus was purified with 57.1-fold increase in the specific activity and a yield of $54.9 \%$ after ultrafiltration followed by CM-Cellulose and Sephadex G-100 column chromatographies [78]. 
As shown, conventional chromatography techniques have been efficiently used to purify pectinolytic enzymes.

\section{INDUSTRIAL APPLICATION}

Pectinase production occupies about $10 \%$ of the overall manufacturing of enzyme preparations. These enzymes are widely used in the food industry in the production of juices, fruit drinks and wines [3].

\subsection{Acid Pectinases}

Acid pectinases, which are widely used in extraction, clarification, and removal of pectin in fruit juices, in maceration of vegetables to produce pastes and purées, and in winemaking, are often produced by fungi, especially Aspergillus niger.

The crushing of pectin-rich fruits results in high viscosity juice which stays linked to the fruit pulp in a gelatinous structure, hindering the juice extraction process by pressing. Pectinase addition in the extraction process improves the fruit juice yield through an easier process, decreases the juice vicosity and degrades the gel structure, thus improving the juice concentration capacity $[5,9]$. In the case of fruit juice, extraction by enzymatic maceration can increase yields by more than $90 \%$ compared to conventional mechanical juicing, besides improving the organoleptic (color, flavor) and nutritional (vitamins) properties and technological efficiency (ease of filtering) [4].

In several processes, pectinolytic enzymes are applied associated with other cell wall degrading enzymes such as cellulases and hemicellulases [79]. The mixture of pectinases and cellulases has been reported to improve more than 100 $\%$ juice extraction yields [5, 9]. Soares and coworkers [73] reported an improvement between three and four times in juice yields from papaya, banana and pear using enzymic extraction instead of the conventional pressing process.

The enzymic treatment can help decrease $62 \%$ of the apple juice viscosity. When the depectinized apple juice is ultrafiltered, the permeate flux is much higher than when undepectinized juice is processed. The increase in the permeation rate is a result of both the reduction in apple juice viscosity and the reduction in total pectin content. Pectin is a fibershaped colloid that causes severe fouling of ultrafiltration membranes [80].

The commercially available pectinase preparations used in food processing are traditionally associations of polygalacturonases, pectin lyases and pectin methyl esterases. These preparations are usually derived from fungi, mainly the genera Aspergillus [3, 10].

\subsection{Alkaline Pectinases}

Alkaline pectinases are generally produced by bacteria, particularly species of Bacillus, but are also made by some filamentous fungi and yeasts $[34,45,81]$. They may be used in the pretreatment of waste water from vegetable foodprocessing that contains pectin residues; the processing of textile fibers such as flax, jute and hemp, coffee and tea fermentation, vegetable-oil extraction and the treatment of paper pulp $[9,45,81,82]$.
Pectinolytic enzymes have been applied to the degumming of jute, sunn hemp, flax, ramie and coconut fibers for textile application [82-84]. Degumming can be done by adding pectinolytic mixtures or by fiber fermentation (dewretting) using pectinase-producing microorganisms $[85,86]$. In order to remove the non-cellulosic gummy material composed mainly of pectin and hemicellulose, Kapoor and coworkers [81] had run three treatments on ramie and sunn hemp bast fibers: enzymic, chemical and chemical associated with enzymic treatment. Of the three treatments, the third one was the most promising for degumming. The scanning electron microscopic studies revealed a complete removal of non-cellulosic gummy material from the surface of ramie and sunn hemp fibres.

Bioscouring is an alternative and more environmentally friendly method to remove non-cellulosic "impurities" from raw cotton by specific enzymes to make the surface more hydrophilic [87]. Pectins are responsible for the hydrophobic properties of raw cotton and its degradation by pectinolytic enzymes was suggested to facilitate also removal of waxes and could thus lead to a considerable reduction rate of water and chemicals consumption and of effluent discharge. In contrast to drastic alkaline conditions conventionally used, this treatment with pectin degrading enzymes would not affect the cellulose backbone and thus avoid fiber damage [32, 33,88 ]. Klug-Santner and coworkers [33] reported up to 80 $\%$ of pectin removal from the outer layer of cotton by a purified endo-pectate lyase from Bacillus pumilus BK2.

During papermaking, alkaline peroxide bleaching of mechanical pulps solubilizes acidic polysaccharides which are troublesome interfering substances. Some of these acidic polysaccharides are pectins, or polygalacturonic acids. The ability of polygalacturonic acids to complex cationic polymers (cationic demand) depends strongly on their degree of polymerization, so monomers, dimers, and trimers of galacturonic acid did not cause measurable cationic demand, but hexamers and longer chains had high cationic demand. Pectinases can depolymerize polymers of galacturonic acid, and consequently lower the cationic demand of pectin solutions and the filtrates from peroxide bleaching $[89,90]$.

Enzymes involved in the breakdown of plant cell wall polyssaccharides can be used to extract vegetal oils, coconut germ, palm, sunflower seed, rape seed olives and kernel oils which are traditionally produced by extraction with organic solvents, such as the potentially carcinogen hexane [9]. By degrading cell wall components like pectin enzymes promote the oil liberation.

According to Angayarkanni and coworkers [91], adding pectinases in association with cellulases, hemicellulases and proteinases to the tea-leaf fermenting bath raises the tea quality index by $5 \%$.

\section{CONCLUSION}

Many studies have been conducted on the production, isolation and characterization of pectinases from various microorganisms, mainly enzymes specific to pectin smooth regions. But a few works have been published about hairy pectin region specific enzymes. The difficulties to obtain the appropriate substrate might be the biggest problem to develop studies with RG-degrading enzymes. 
There are a lot of industrial processes to which pectinases can be applied to improve the quality and the yield of final products. In this way, it is important to investigate the production conditions and physico-chemical characteristics of new enzymes. Screening a large number of microorganisms for high active enzymes combined with protein engineering, direct evolution and metagenome approaches can lead to more efficient and stable enzymes. Enzymes having a set of biochemical and physical properties can be generated for each specific industrial process.

Pectinases structures have been solved by cristalography and nuclear magnetic resonance techniques allowing for the elucidation of the molecular basis behind substrate specificity. The future efforts into pectinase research should be concentrated on elucidation of the regulatory mechanism of enzymes secretion at the molecular level and the mechanism of action of different pectinolytic enzymes towards pectic substrates. These studies can provide valuable tools to manipulate microorganisms making them able to produce efficient enzymes in high amounts.

\section{ACKNOWLEDGEMENT}

The authors are grateful to FUNDUNESP (Fundação para o Desenvolvimento da UNESP) and CNPq (Conselho Nacional de Desenvolvimento Científico e Tecnológico) for financial support.

\section{REFERENCES}

[1] Antranikian G. Microbial degradation of starch. In: Winkelmann G, Ed. Microbial degradation of natural products. VCH, Weinheim 1992, 27-51.

[2] Kaur G, Kumar S, Satyanarayana T. Production, characterization and application of a thermostable polygalacturonase of a thermophilic mould Sporotrichum thermophile Apinis. Bioresour Technol 2004; 94: 239-43

[3] Semenova M, Sinitsyna O, Morozova V, et al. Use of a preparation from fungal pectin lyase in the food industry. Appl Biochem Microbiol 2006; 42: 598-602.

[4] Rombouts FM, Pilnik W. Pectic enzymes. In: Rose AH, Ed. Microbial Enzymes and Bioconversions. Academic Press, London 1980; 5: 227-72.

[5] Alkorta I, Gabirsu C, Lhama MJ, Serra JL. Industrial applications of pectic enzymes: a review. Proc Biochem 1998; 33: 21-8.

[6] Jayani RS, Saxena S, Gupta R. Microbial pectinolytic enzymes: A review. Process Biochem 2005; 40: 2931-44.

[7] Willats WGT, Knox P, Mikkelsen JD. Pectin: new insights into an old polymer are starting to gel. Trends Food Sci Technol 2006; 17: 97-104.

[8] Vincken JP, Schols HA, Oomen RJFJ, et al. If homogalacturonan were a side chain of rhamnogalacturonan I: implications for cell wall architecture. Plant Physiol 2003; 132: 1781-9.

[9] Kashyap DR, Vohra PK, Tewari R. Application of pectinases in the commercial sector: a review. Bioresour Technol 2001; 77: 215-27.

[10] Gummadi SN, Panda T. Purification and biochemical properties of microbial pectinases - a review. Proc Biochem 2003; 38: 987-96.

[11] Lang C, Dörnenburg H. Perspectives in the biological function and the technological application of polygalacturonases. Appl Microbiol Biotechnol 2000; 53: 366-75

[12] Sakai T, Sakamoto T, Hallaert J, Vandamme E. Pectin, pectinase and protopectinase: production, properties and applications. Adv Appl Microbiol 1993; 39: 213-94.

[13] Coutinho PM, Henrissat B. Carbohydrate-active enzymes: an integrated database approach. In "Recent Advances in Carbohydrate Bioengineering", Gilbert HJ, Davies G, Henrissat B, Svensson B. Eds. Cambridge: The Royal Society of Chemistry 1999; 3-12. [cited 2008 Aug 05]. Available from: http://www.cazy.org/

[14] Shevchik VE, Hugouvieux-Cotte-Pattat N. Identification of a bacterial pectin acetyl esterase in Erwinia chysanthemi 3937. Mol Microbiol 1997; 24(6): 1285-301.
[15] Devi NA, Rao AGA. Fractionation, purification and preliminary characterization of polygalacturonases produced by Aspergillus carbonarius. Enzyme Microb Technol 1996; 18: 59-65.

[16] Jacob N, Poorna AC, Prema P. Purification and partial characterization of polygalacturonase from Streptomyces lydicus. Bioresour Technol 2008; 99: 6697-701.

[17] Contreas-Esquivel JC, Voget CE. Purification and partial characterization of na acid polygalacturonase from Aspergillus kawakii. J Biotechnol 2004; 110: 21-8.

[18] Dinu D, Nechifor MT, Stoian G, Costache M, Dinischiotu A. Enzymes with new biochemical properties in the pectinolytic complex produced by Aspergillus niger MIUG 16. J Biotechnol 2007; 131: 128-37.

[19] Kobayashi T, Higaki N, Yajima N, et al. Purification and properties of a galacturonic acid-releasing exopolygalacturonase from a strain of Bacillus. Biosci Biotechnol Biochem 2001; 65(4): 842-7.

[20] Niture SK, Pant A. Purification and biochemical characterization of polygalacturonase II produced in semi-solid médium by a strain of Fusarium moliniforme. Microbial Res 2004; 159: 305-14.

[21] Gadre RV, Driessche GV, Beeumen JV, Bhat MK. Purification, characterization and mode of action of an endo-polygalacturonase from the psychrophilic fungus Mucor flavus. Enzyme Microb Technol 2003; 32: 321-30.

[22] Ortega N, De Diego S, Perez-Mateos M, Busto MD. Kinetic properties and thermal behaviour of polygalacturonase used in fruit juice clarification. Food Chem 2004a; 88: 209-17.

[23] Chellegatti MASC, Fonseca MJV, Said S. Purification and partial characterization of exopolygalacturonase I from Penicillium frequentans. Microbiol Res 2002; 157: 19-24.

[24] Barense RI, Chellegatti MASC, Fonseca MJV, Said S. Partial purification and characterization of exopolygalacturonase II and III of Penicillium frequentans. Braz J Microbiol 2001; 32: 327-30.

[24] Saito K, Takakuwa N, Oda Y. Purification of the extracellular pectinolytic enzyme from the fungus Rhizopus oryzae NBRC 4707. Microbial Res 2004; 159: 83-6.

[26] Martins ES, Silva D, Leite RSR, Gomes E. Purification and characterization of polygalacturonase produced by thermophilic Ther moascus aurantiacus CBMAI-756 in submerged fermentation. Antonie van Leeuwenhoek 2007; 91: 291-9.

[27] Pitt D. Pectin Lyase from Fhoma medicaginis var. pinodella. Methods Enzymol 1988; 161: 350-4

[28] Sinitsyna OA, Fedorova EA, Semenova MV, et al. Isolation and characterization of extracellular pectin lyase from Penicillium canescens. Biochem (Moscow) 2007; 72(5): 565-71.

[29] Van Alebeek GJWM, Christensen TMIE, Schols HE, Mikkelsen JD, Voragen AGJ. Mode of action of pectin lyase A of Aspergillus niger on differently $\mathrm{C}_{6}$-substituted oligogalacturonides. $\mathrm{J}$ Biol Chem 2002; 277(29): 25929-36

[30] Semenova MV, Grishutin SG, Gusakov AV, Okunev ON, Sinitsyn AP. Isolation and properties of pectinases from the fungus Aspergillus japonicus. Biochem (Moscow) 2003; 68(5): 559-69.

[31] Pedrolli DB. Caracterização fisico-química de pectinases extracelulares purificadas de Aspergillus giganteus. M.Sc. Thesis, São Paulo State University 2008, Rio Claro, São Paulo, Brazil.

[32] Morozova VV, Semenova MV, Salanovich TN, et al. Application of neutral-alkaline pectate lyase to cotton fabric boil off. Appl Biochem Microbiol 2006; 42: 603-8.

[33] Klug-Santner BG, Schnitzhofer W, Vrsanská M, et al. Purification and characterization of a new bioscouring pectate lyase from Bacillus pumilus BK2. J Biotechnol 2006; 121: 390-401.

[34] Kashyap DR, Chandra S, Kaul A, Tewari R. Production, purification and characterization of pectinase from a Bacillus sp. DT7. World J Microbiol Biotechnol 2000; 16: 277-82.

[35] Kobayashi T, Hatada Y, Higaki N, et al. Enzymatic properteis and deduced amino acid sequence of a high-alkaline pectate lyase from an alkaliphilic Bacillus isolate. Biochim Biophys Acta 1999; 1427: 145-54.

[36] Soriano M, Diaz P, Pastor FIJ. Pectinolytic systems of two aerobic sporogenous bacterial strains with high activity on pectin. Curr Microbiol 2006; 50: 114-8

[37] Gummadi SN, Kumar DS. Optimization of chemical and physical parameters affecting the activity of pectin lyase and pectate lyase from Debaryomyces nepalensis: a statistical approach. Biochem Eng J 2006; 30: 130-7.

[38] Ortega N, De Diego S, Rodriguez-Nogales JM, Perez-Mateos M, Busto MD. Kinetic behaviour and thermal inactivation of pectin- 
lyase used in food processing. Int J Food Sci Technol 2004b; 39: 631-9.

[39] Alaña A, Alkorta I, Domíngez JB, Llama MJ, Serra JL. Pectin lyase activity in a Penicillium italicum strain. Appl Environ Microbiol 1990; 56 (12): 3755-9.

[40] Mutter M, Beldman G, Schols HA, Voragen AGJ. Rhamnogalacturonan $\alpha$-L-Rhamnopyranohydrolase: a novel enzyme specific for the terminal nonreducing rhamnosyl unit in rhamnogalacturonan regions of pectin. Plant Physiol 1994; 106: 241-50.

[41] Mutter M, Renard CMGC, Beldman G, Schols HA, Voragen AGJ. Mode of action of RG-hydrolase and RG-lyase toward rhamnogalacturonan oligomers: characterization of degradation products using RG-rhamnohydrolase and RG-galacturonohydrolase. Carbohydr Res 1998; 311: 155-64.

[42] Mutter M, Colquhoun IJ, Schols HA, Beldman G, Voragen AGJ. Rhamnogalacturonase B from Aspergillus aculeatus is a rhamnogalacturonan $\alpha$-L-rhamnopyranosyl-( $1 \rightarrow 4)$ - $\alpha$-D-galactopyranosyluronide lyase. Plant Physiol 1996: 110: 73-7.

[43] Searle-Van Leeuwen MJF, Van Den Broek LAM, Schols HA, Beldman G, Voragen AGJ. Rhamnogalacturonan acetylesterase: a novel enzyme from Aspergillus aculeatus, specific for the deacetylation of hairy (ramified) regions of pectins. Appl Microbiol Biotechnol 1992; 38: 347-9.

[44] Vlugt-Bergmans CJB, Meeuwsen PJA, Voragen AGJ, Van Ooyen AJJ. Endo-xylogalacturonan hydrolase, a novel pectinolytic enzyme. Appl Environ Microbiol 2000; 66(1): 36-41.

[45] Hoondal GS, Tiwari RP, Tewari R, Dahiya N, Beg QK. Microbial alkaline pectinases and their industrial applications: a review. Appl Microbiol Biotechnol 2002; 59: 409-18.

[46] Minjares-Carranco A, Trejo-Aguilar BA, Aguilar G, ViniegraGonzález G. Physiological comparison between pectinaseproducing mutants of Aspergillus niger adapted either to solid-state fermentation or submerged fermentation. Enzyme Microb Technol 1997; 21: 25-31.

[47] Naidu GSN, Panda T. Studies on $\mathrm{pH}$ and thermal deactivation of pectolytic enzymes from Aspergillus niger. Biochem Eng J 2003; 16: 57-67.

[48] Naessens M, Vandamme EJ. Multiple forms of microbial enzymes. Biotechnol Lett 2003; 25: 1119-24.

[49] De Lorenzo G, D'ovidio R, Cervone F. The role of polygalacturonase inhibiting proteins (PGIPS) in defense against pathogenic fungi. Ann Rev Phytopathol 2001; 39: 313-35.

[50] Kars I, Krooshof GH, Wagemakers L, Joosten R, Benen JAE, Kan JAL. Necrotizing activity of five Botrytis cinerea endopolygalacturonases produced in Pichia pastoris. Plant J 2005; 43: 213-25.

[51] Juge N. Pant Protein Inhibitors of Cell Wall Degrading Enzymes. Trends Plant Sci 2006; 11:359-67.

[52] Di Matteo A, Bonivento D, Tsernoglou D, Frederici L, Cervone F. Polygalacturonase-inhibiting protein (PGIP) in plant defence: a structural view. Phytochem 2006; 67: 528-33.

[53] Frederici L, Di Matteo A, Fernadez-Recio J, Tsernoglou D, Cervone F. Polygalacturonase inhibiting proteins: players in plant innate immunity? Trends Plant Sci 2006; 11(2): 65-70.

[54] Herron SR; Benen JA, Scavetta RD, Visser J, Jurnak F. Structure and function of pectic enzymes: virulence factors of plant pathogens. Proc Nati Acad Sci USA 2000; 97: 8762-9.

[55] Caprari C, Bergmann C, Migheli Q, et al. Fusarium moniliforme secretes four endopolygalacturonases derived from a single gene product. Physiol Mol Plant Pathol 1993; 43: 453-62.

[56] Bussinik HJ, Buxton FP, Fraaye BA, De Graaff LH, Visser J. The polygalacturonases of Aspergillus niger are encoded by a family of diverged genes. Eur J Biochem 1992; 208: 83-90.

[57] Parenicova L, Benen JAE, Kester HCM, Visser J. pgaE encodes a fourth member of the endopolygalacturonase gene family from Aspergillus niger. Eur J Biochem 1998; 251: 72-80.

[58] Cruickshank RH, Wade GC. Detection of pectic enzymes in pectinacrylamide gels. Anal Biochem 1980; 107: 177-81.

[59] Magro P, Di Lenna P, Marciano P, Pallavicini C. Variability of polygalacturonase and protein isoelectric focusing patterns in Botrytis cinerea isolates. J Gen Microbiol 1980; 120: 105-9.

[60] Di Lenna P, Fielding AH. Multiple forms of polygalacturonase in apple and carrot tissue infected by isolates of Botrytis cinerea. J Gen Microbiol 1983; 129: 3015-8.

[61] Johnston DJ, Williamson B. Purification and characterization of four polygalacturonases from Botrytis cinerea. Mycol Res 1992; 96: 343-9.
[62] Tobias R, Conway W, Sams C. Polygalacturonase isozymes from Botrytis cinerea grown on apple pectin. Biochem Mol Biol Int 1993; 30: 829-37.

[63] Lee TH, Kim BY, Chung YR, Lee SY, Lee CW, Kim JW. Purification and characterization of an exo-polygalacturonase from Botrytis cinerea. J Microbiol 1997; 35: 134-40.

[64] Rha E, Park HJ, Kim MO, Chung YR, Lee CW, Kim JW. Expression of exo-polygalacturonases in Botrytis cinerea. FEMS Microbiol Lett 2001; 201: 105-9.

[65] Coutinho PM, Stam M, Blanc E, Henrissat B. Why are there so many carbohydrate-active enzyme-related genes in plants? Trends Plant Sci 2003; 8: 563-5.

[66] Carroll SB, Grenier JK, Weatherbee SD. From DNA to diversity: Molecular genetics and the evolution of animal design, Blackwell Scientific 2nd ed, Malden 2005.

[67] Fraissinet-Tachet L, Fevre M. Regulation by galacturonic acid of pectinolytic enzyme production by Sclerotinia sclerotiorum. Curr Microbiol 1996; 33: 49-53.

[68] Cooper RM. The mechanisms and significance of enzymic degradation on host cell walls. In: Callow JA, Ed. Biochemical Plant Pathology. Wiley, Chichester, New York 1983, 101-37.

[69] De Vries RP, Jansen J, Aguilar G, et al. Expression profiling of pectinolytic genes from Aspergillus niger. FEBS Lett 2002; 530: 41-7.

[70] Castilho LR, Medronho RA, Alves TLM. Production and extration of pectinases obtained bu solid state fermentation of agroindustrial residues with Aspergillus niger. Bioresour Technol 2000; 71: 4550 .

[71] Silva D, Martins ES, Silva R, Gomes E. Pectinase production by Penicillium viridicatum RFC3 by solid state fermentation using agricultural wastes and agro-industrial by-products. Braz J Microbiol 2002; 33: 318-24.

[72] Pedrolli DB, Gomes E, Monti R, Carmona EC. Studies on productivity and characterization of polygalacturonase from Aspergillus giganteus submerged culture using citrus pectin and orange waste. Appl Biochem Biotechnol 2008; 144(2): 191-200.

[73] Soares MMCN, da Silva R, Carmona EC, Gomes E. Pectinolytic enzyme production by Bacillus species and their potential application on juice extraction. J Microbiol Biotechnol 2001; 17: 79-82.

[74] Sunnotel O, Nigam P. Pectinolytic activity of bacteria isolated from soil and two fungal strains during submerged fermentation. World $\mathrm{J}$ Microbiol Biotechnol 2002; 18: 835-9.

[75] Hölker U, Lenz J. Solid-state fermentation - are there any biotechnological advantages? Curr Opin Microbiol 2005; 8: 301-6.

[76] Naidu GSN, Panda T. Production of pectolytic enzymes - a review. Bioprocess Eng 1998; 19: 355-61.

[77] Celestino SMC, Freitas SM, Medrano FJ, De Sousa MV, FerreiraFilho EX. Purification and characterization of a novel pectinase from Acrophialophora nainiana. J Biotechnol 2006; 123: 33-42.

[78] Yadav S, Yadav PK, Yadav D, Yadav KDS. Purification and characterization of an alkaline pectin lyase from Aspergillus flavus. Process Biochem 2008; 43: 547-52.

[79] Bhat MK. Cellulases and related enzymes in biotechnology. Biotech Adv 2000; 18: 355-83.

[80] Alvarez S, Alvarez R, Riera FA, Coca J. Influence of depectinization on apple juice ultrafiltration. Colloids Surf 1998; 138: 377-82.

[81] Kapoor M, Beg QK, Bhushan B, Singh K, Dadhich KS, Hoondal GS. Application of an alkaline and thermostable polygalacturonase from Bacillus sp. MG-cp-2 in degumming of ramie (Boehmeria nivea) and sunn hemp (Crotalaria juncea) bast fibers. Proc Biochem 2001; 36: 803-7.

[82] Zhang J, Henriksson G, Johansson G. Polygalacturonase is the key component in the enzymatic retting of flax. J Biotechnol 2000; 81 : 85-9.

[83] Chesson A. Maceration in relation to the post handling and processing of plant material. J Appl Biotechnol 1980; 48: 1-45.

[84] Bruhlmann F, Kim KS, Zimmerman W, Fiechter A. Pectinolytic enzymes from actinomycetes for the degumming of ramie bast fibers. Appl Environ Microbiol 1994; 60: 2107-12.

[85] Sharma HSS. Screening of polysaccharide-degrading enzyme for retting flax stem. Int Biodeter 1987; 23: 1981-6.

[86] Molina SMG, Pelissari FA, Vitorello CBM. Screening and genetic improvement of pectinolytic fungi for degumming of textile fibers. Braz J Microbiol 2001; 32: 320-6. 
[87] Li Y, Hardin IR. Enzymatic scouring of cotton-surfactants, agitation, and selection of enzymes. Textile Chemist Colorist 1998; 30(9): 23-9.

[88] Waddell RB. Bioscouring of cotton: commercial applications of alkaline stable pectinase. AATCC Review 2002; 2: 28-30.

[89] Reid I, Ricard M. Pectinase in papermaking: solving retention problems in mechanical pulps bleached with hydrogen peroxide. Enzyme Microb Technol 2000; 26: 115-23.
[90] Reid I, Ricard M. Purified pectinase lowers cationic demand in peroxide-bleached mechanical pulp. Enzyme Microb Technol 2004; 34: 499-504.

[91] Angayarkanni J, Palaniswamy M, Murugesan S, Swaminathan K. Improvement of tea leaves fermentation with Aspergillus spp. pectinase. J Biosci Bioeng 2002; 94: 299-303.

Received: September 3, 2008

Revised: December 1, 2008

Accepted: December 16, 2008

(C) Pedrolli et al.; Licensee Bentham Open.

This is an open access article licensed under the terms of the Creative Commons Attribution Non-Commercial License (http://creativecommons.org/licenses/ by-nc/3.0/) which permits unrestricted, non-commercial use, distribution and reproduction in any medium, provided the work is properly cited. 